\title{
Sosialisasi Edukasi dalam Upaya Meningkatkan Spiritualitas Umat pada Masa Pandemic COVID-19
}

\author{
Aletheia Pattiasina, Apin Manuhutu, Feronika Lambiombir, Denia Koritelu, Megawati Matital, \\ Sadrak Wutres, Rivaldo Mail, Beatrix J.M. Salenussa, \& Martha Patty*
}

Universitas Kristen Indonesia Maluku, Indonesia

\begin{abstract}
Pandemic COVID-19 telah membawa pengaruh besar terhadap kehidupan normal masyarakat saat ini. Ruang perjumpaan yang biasanya terjadi secara luring (di luar jaringan) berubah menjadi pertemuan daring (di dalam jaringan) karena adanya anjuran physical distancing sebagai salah satu upaya untuk mencegah penularan COVID-19 yang merupakan kebijakan pemerintah pusat maupun daerah untuk dilaksanakan dalam lini kehidupan masyarakat, bahkan kebijakan tersebut kemudian membuat sinode Gereja Protestan Maluku pun harus mengatur kebijakan pelayanan. Untuk membantu kebijakan pelayanan tersebut kelompok 1 KKN Universitas Kristen Indonesia Maluku yang berada di Klasis Kota Ambon, kemudian melaksanakan berbagai program kegiatan yang bertujuan untuk mengedukasi umat agar mengetahui dengan benar tentang COVID-19 dan bagaimana meningkatkan spiritualitas umat dalam beribadah selama masa pandemic COVID-19. Program kegiatan ini menggunakan metode pemberian edukasi dan sosialisasi terkait COVID-19 dan upaya meningkatkan spiritualitas umat. Kegiatan ini berupaya untuk mengedukasi umat dan masyarakat tentang kesadaran menerapan 5M dan upaya meningkatkan spiritualitas umat dalam beribadah, baik secara offline dan online melalui webinar dengan menggunakan aplikasi zoom. Program kegiatan ini dilaksanakan dalam bentuk pengadaan dan pemasangan spanduk penerapan protokol kesehatan 5M di 3 lokasi (jembatan Putih, tempat putar oto dan gereja Gloria yang baru), untuk mengedukasi anggota jemaat dan masyarakat agar sadar menerapkan protokol kesehatan 5M; Pengadaan dan pemberian Masker, sabun cuci tangan dan tissue sebanyak 13 buah sesuai jumlah sektor yang ada di Jemaat GPM Ebenhaezer yaitu 13 sektor pelayanan, dan Webinar tentang "Fenomena COVID-19 dan peningkatan spiritualitas umat" yang melibatkan beberapa jemaat di klasis kota Ambon yakni Jemaat GPM Ebenhaezer, Jemaat GPM Kategorial Polri Bukit Kasih, Jemaat GPM Bukit Doa, Jemaat GPM Syaloom, dan Jemaat GPM Imanuel. Kegiatan ini berdampak positif bagi jemaat dan masyarakat di klasis kota Ambon, terutama di Jemaat GPM Ebenheizer-Skip yang merupakan kawasan Zona Merah. Jemaat dan masyarakat menjadi lebih paham pentingnya menerapkan protokol kesehatan melalui giat 5M untuk menjaga kesehatan diri dan lebih memahami pentingnya spiritualitas umat dalam pelaksanaan ibadah dari dan di rumah di masa pandemic COVID-19 sebagai wujud mempertahankan kehidupan di tengah pandemic COVID-19.
\end{abstract}

Keywords: Sosialisasi edukasi; COVID-19; Spiritualitas Umat; Jemaat GPM Ebenhaezer

\section{Introduction}

Severe Acute Respiratory Syndrome Coronavirus 2 (SARS-CoV-2) atau yang dikenal sebagai virus corona, merupakan jenis baru dari corona virus yang dapat menyebabkan penyakit Coronavirus Disease-2019 (COVID19)(Yuliana, n.d.). Apabila virus ini menjangkit manusia, maka dapat menyebabkan penyakit infeksi saluran pernapasan, mulai dari flu biasa hingga penyakit serius lainnya seperti Middle East Respiratory Syndrome (MERS)

\footnotetext{
* Corresponding author:

E-mail address: altchr01@gmail.com
} 
dan Serve Acute Respiratory Syndrome (SARS). Virus baru ini yang mewabah pertama kalinya di Wuhan-Tiongkok, pada bulan Desember tahun 2019 (Baloch et al., 2020), telah menular dengan cepat dan hampir seluruh negara terkena dampak dari virus corona termasuk Indonesia. Penyebaran virus ini menyebabkan berbagai bidang terkena dampaknya diantaranya: bidang kesehatan, pendidikan, integrasi sosial, maupun sektor produksi. Akibatnya setiap Negara mengambil kebijakan dengan meminta rakyatnya untuk tetap di rumah, menjaga jarak baik secara fisik (physical distancing) maupun sosial (social distancing), bahkan melakukan lockdown (karantina wilayah) untuk menghambat penyebaran virus corona tersebut(Ade Miranti Karunia, n.d.). Sampai saat ini di Indonesia sudah lebih dari 3 juta orang terkonfirmasi positif COVID-19 dan 120 ribu orang meninggal dunia akibat COVID-19 (Satgas Covid-19, 2021).

Menyikapi permasalahan ini pemerintah Indonesia, baik di tingkat Pusat sampai di tingkat Provinsi dan Kabupaten/Kota mengeluarkan berbagai kebijakan. Kebijakan baru yang dikeluarkan oleh pemerintah Indonesia berupaya untuk menangani penyebaran COVID-19 secara khusus mengurangi mobilitas dengan pemberlakuan pembatasan kegiatan masyarakat (PPKM). Pemerintah Kota Ambon menjawab instruksi mentri dalam negeri No. 17 tahun 2021 dengan menerapkan Instruksi Walikota Ambon No. 3 tahun 2021 butir kesembilan point H yang menyatakan bahwa "pelaksanaan kegiatan ibadah (pada tempat ibadah), masjid, musolah, gereja, pura, dan wihara serta tempat umum lainnya difungsikan sebagai tempat ibadah ditiadakan untuk sementara waktu sampai pada wilayah dimaksud dinyatakan aman berdasarkan penetapan Walikota dan lebih mengoptimalkan ibadah di rumah (Instruksi Walikota Ambon, 2021).

Sejalan dengan instruksi ini, GPM melalui MPH Sinode mengatur kebijakan pelayanan di jemaat-jemaat sesuai situasi dan kondisi penanganan COVID-19. Termasuk Jemaat GPM Ebenhaezer yang adalah salah satu jemaat yang berada di kawasan zona merah penyebaran COVID-19 di Kota Ambon. Jemaat GPM Ebenhaezer GPM yang terletak di Klasis kota Ambon, memiliki 3.968 anggota jemaat, yang terdiri dari 2001 orang laki-laki dan 1967 orang perempuan yang terbagi dalam 13 sektor pelayanan dan 33 unit pelayanan (Ebenhaezer, n.d.). Berdasarkan data yang diperoleh, Jemaat GPM Ebenhaezer terindetifikasi sebagai kawasan zona merah karena ada beberapa anggota jemaat yang terindentifikasi menderita COVID, walaupun berdasarkan data terdapat satu anggota jemaat yang meninggal karena COVID-19. Hal ini menunjukkan bahwa kurangnya kesadaran warga jemaat dalam menerapkan protokol kesehatan maupun giat 5M. Kurangnya kesadaran ini, dilihat melalui hasil pengamatan kelompok 1 selama berada di Jemaat GPM Ebenhaezer, yang menunjukkan kurangnya kesadaran dan kepedulian bukan saja warga jemaat tapi juga masyarakat yang berada disekitarnya dalam mentaati kebijakan yang dikeluarkan oleh pemerintah misalnya: menggunakan masker, mencuci tangan, menghindari kerumunan, dan lain sebagainya. Ketidakpatuhan dalam mentaati kebijakan pemerintah ini berdasarkan pengamatan kelompok 1 tergambar ketika ada beberapa lokasi tempat tinggal yang dijadikan tempat kerumunan dan ada juga warga yang tidak memakai masker monad-mandir berjalan maupun mengenderai kenderaan beroda dua maupun becak.

Berdasarkan realita ini, maka Majelis Jemaat GPM Ebenhaezer berinisiatif menjalin kerjasama dengan Ketua RT dan Ketua RW setempat bersama Puskesmas Kayu Putih untuk melakukan sosialisasi penerapan prokes 5M dan Vaksinasi kepada masyarakat dan warga Jemaat GPM Ebenhaezer. Hasilnya kegiatan kerjasama tersebut hanya dihadiri oleh sebagian kecil masyarakat dan warga Jemaat GPM Ebenhaezer. Ketidakpedulian masyarakat dan lebih khusus warga Jemaat GPM Ebenhaezer ini pun juga terdampak pada belum adanya kesadaran masyarakat dan warga jemaat untuk menjaga kesehatan agar terhindar dari COVID-19.

Terlepas dari kurangnya kesadaran masyarakat terhadap pentingnya protokol kesehatan dan giat 5M untuk menghindari COVID-19, khusus bagi warga Jemaat GPM Ebenhaezer, kelompok KKN-LSPB juga menunjukkan pengamatannya terhadap kurangnya kesadaran umat untuk meningkatkan nilai spiritualitas dalam beribadah. Sebagaimana kita ketahui bukan saja bagi warga Jemaat GPM Ebenhaezer, tetapi semua warga jemaat di lingkup GPM melalui kebijakan pelayanan, mengarahkan setiap warga jemaatnya untuk melaksanakan setiap ibadah di rumah masing-masing melalui siaran kebaktian di YouTube dan TV kabel, sebagaimana ditunjukkan berdasarkan arahan MPH Sinode GPM No. 3/SND/D. 14/3/2021 tentang petunjuk teknis pelaksanaan pelayanan GPM dalam masa penanganan pandemic COVID-19. Melalui pengamatan tersebut, maka terekam bahwa ternyata anggota jemaat ada yang tidak mengikuti ibadah dari dan di rumah dengan baik, selain itu juga hasil pengumpulan kolekta di rumahrumah warga jemaat menunjukkan bahwa hanya $20 \%$ warga jemaat yang melaksanakan ibadah (Koritelu, n.d.). 
Kurangnya kesadaran dalam menataati protokol kesehatan untuk menghindari COVID-19 dan juga kurangnya kesadaran warga Jemaat GPM Ebenhaezer untuk meningkatkan spiritualitas melalui ibadah pada masa COVID-19. Kuliah Kerja Nyata (KKN) Universitas Kristen Indonesia Maluku (UKIM) pada masa pandemi ini diprogramkan untuk dilaksanakan pada kawasan tempat tinggal mahasiswa sehingga mempermudah pelaksanaan program kerja yang direncanakan serta mempermudah koordinasi dengan jemaat/masyarakat terkait. Mahasiswa juga didampingi secara online untuk bagaimana memprogramkan kegiatan-kegiatan serta menulis kronologis hasilnya berupa artikel hasil pengabdian masyarakat (Touwely et al., 2019). Kelompok 1 yang berada di Klasis Kota Ambon, kemudian melaksanakan berbagai program kegiatan yang bertujuan untuk mengedukasi umat agar mengetahui dengan benar tentang COVID-19 dan bagaimana meningkatkan spiritualitas umat dalam beribadah selama masa pandemic COVID19. Kesadaran anggota jemaat untuk beribadah melalui media youtube, tv dan media sosial lain sangat kurang. Hal ini terlihat dari sikap merekadalam mengikuti ibadah sambil beraktivitas yang lain (Wahyu S. Wibowo, 2020). Kegiatan yang diupayakan oleh kelompok kiranya mampu mengedukasi umat dan masyarakat tentang kesadaran menerapan $5 \mathrm{M}$, serta meningkatkan spiritualitas umat dalam beribadah baik secara offline dan online.

Kegiatan-kegiatan ini dilaksanakan dalam bentuk pengadaan dan pemasangan spanduk penerapan protokol kesehatan 5M di 3 lokasi (jembatan Putih, tempat putar oto dan gereja Gloria yang baru), untuk mengedukasi anggota jemaat dan masyarakat agar sadar menerapkan protokol kesehatan 5M; Pengadaan dan pemberian Masker, sabun cuci tangan dan tissue, serta kegiatan Webinar dengan tema: "Fenomena COVID-19 dan peningkatan spiritualitas umat" yang juga melibatkan beberapa Jemaat di Klasis Kota Ambon yakni Jemaat GPM Ebenhaezer, Jemaat GPM Kategorial Polri Bukit Kasih, Jemaat GPM Bukit Doa, Jemaat GPM Syaloom, dan Jemaat GPM Imanuel. Kegiatan ini berdampak positif bagi jemaat dan masyarakat di klasis Kota Ambon, terutama di Jemaat GPM Ebenheizer-Skip yang merupakan kawasan Zona Merah. Kegiatan-kegiatan tersebut diharapkan dapat memberikan peningkatan kesadaran bagi warga jemaat untuk sadar terhadap bahaya COVID-19 bagi kesehatan tubuh dan jiwa, tetapi juga upaya warga jemaat untuk lebih mendekatkan diri kepada Tuhan melalui ibadah-ibadah yang berlangsung di rumah-rumah Jemaat sebagai wujud mempertahankan kehidupan di tengah pandemic COVID-19.

\section{Permasalahan Prioritas Mitra}

Berdasarkan permasalahan-permasalahan yang dihadapi oleh Jemaat Mitra, maka yang merupakan fokus permasalahan perioritas mitra yang diangkat oleh kelompok 1 adalah:

1. Kurangnya kesadaran warga jemaat terhadap pentingnya penerapan Protokol kesehatan 5M (memakai masker, mencuci tangan, menjaga jarak, mengurangi mobilitas dan menghindari kerumunan) di masa Pandemic COVID-19.

2. Kurangnya kesadaran warga jemaat untuk melaksanakan ibadah dari dan di rumah di masa pandemic COVID-19.

Dua masalah di atas menjadi masalah prioritas mitra yang menjadi pilihan kelompok, karena berhadapan langsung dengan realita yang terjadi di Jemaat. Hal ini menunjukkan bahwa sampai saat ini COVID-19 masih terus ada. Berbagai upaya telah dilakukan oleh pemerintah untuk memutuskan mata rantai COVID-19. Salah satu kebijakan yang terjadi saat ini, yaitu PPKM. Arahan Presiden Republik Indonesia yang ditindaklanjuti oleh Kementerian dalam Negeri melalui Instruksi Mentri dalam Negeri yang ditunjukan kepada seluruh Provinsi dan kabupaten/kota untuk memberlakukan PPKM Darurat dan PPKM Mikro di daerah-daerah yang terdampak virus corona. Pemerintah Provinsi Maluku, khususnya Kota Ambon. Melalui instruksi Walikota Ambon, menunjukkan bahwa salah satu point dalam instruksi Walikota Ambon, yaitu proses peribadahan di gedung gereja dihentikan sementara. Jemaat-jemaat yang berada pada zona merah, harus melakukan peribadahan pada rumah masing-masing (Instruksi Walikota Ambon, 2021).

Ketidakpatuhan anggota Jemaat GPM Ebenhaezer dalam mematuhi protokol kesehatan dengan baik sangat berhubungan dengan fokus permasalahan pertama, hal ini dapat ditunjukkan melalui hasil pengamatan kelompok 1 di Jemaat GPM Ebenhaezer yang antara lain: ada warga Jemaat yang memakai masker tapi maskernya tidak menutupi mulut dan hidung, ada yang berkerumunan tanpa menggunakan masker, dan ada yang lupa untuk menjaga jarak. Untuk permasalahan kedua dapat dijelaskan berdasarkan hasil pengamatan bahwa dalam proses peribadahan, umumnya warga jemaat yang sudah terbiasa melakukan ibadah di gedung gereja, ketika harus berhadapan dengan 
COVID-19 yang mengakibatkan berbagai kebijakan pemerintah untuk memutuskan mata rantai COVID-19, maka setiap ibadah yang dilakukan di rumah masing-masing, dianggap hanya biasa-biasa saja. Ada yang beribadah sambil berjualan, beribadah sambil masak, beribadah sambil tidur, dll. Hal ini dikarenakan ada yang beranggapan bahwa ibadah di gereja lebih terasa hikmatnya dari pada di rumah, ada yang beranggapan bahwa hanya online di YouTube atau media sosial lainnya sehingga dengan tidak beribadah di jam ibadah pun, kapan saja bisa diakses setelah semua pekerjaan selesai tanpa memikirkan makna ibadah yang baik dan benar adalah ibadah sebagai ungkapan syukur, harapan dan doa kepada Allah.

\section{Solusi Permasalahan}

Berdasarkan dua permasalahan peroritas mitra yang terlihat melalui hasil pengamatan kelompok yaitu:

1. Kurangnya kesadaran warga jemaat terhadap pentingnya penerapan Protokol kesehatan 5M (memakai masker, mencuci tangan, menjaga jarak, mengurangi mobilitas dan menghindari kerumunan) di masa Pandemic COVID-19.

2. Kurangnya kesadaran warga jemaat untuk melaksanakan ibadah dari dan di rumah di masa pandemic COVID-19.

Dari dua masalah tersebut di atas, maka solusi yang dilakukan oleh kelompok 1 adalah sosialisasi edukasi dalam bentuk kegiatan sebagai berikut:

1. Webinar melalu aplikasi zoom dengan tema: "Fenomena COVID-19 dan Peningkatan Spiritualitas Umat" yang melibatkan anggota jemaat Ebenhaezer dan 6 jemaat lain, yakni: Jemaat GPM Kategorial Polri Bukit Kasih, Jemaat GPM Bukit Doa, Jemaat GPM Syaloom, dan Jemaat GPM Imanuel. Hasil dari sosialisasi ini diharapkan, warga jemaat serta para pelayan memiliki kesadaran terhadap bahaya COVID-19 bagi kesehatan tubuh dan jiwa, tetapi juga upaya warga jemaat untuk lebih mendekatkan diri kepada Tuhan melalui ibadahibadah yang berlangsung di rumah-rumah Jemaat sebagai wujud mempertahankan kehidupan di tengah pandemic COVID-19.

2. Pengadaan dan pemasangan Spanduk di 3 lokasi (jembatan Putih, tempat putar mobil angkutan umum dan gereja Gloria yang baru). Kegiatan ini dilakukan untuk mengedukasi anggota jemaat dan masyarakat untuk sadar menerapkan protokol kesehatan $5 \mathrm{M}$.

3. Pengadaan serta pemberian Masker, sabun cuci tangan dan tissue sebanyak 13 buah sesuai jumlah sektor yang ada di jemaat GPM Ebenhaezer yaitu 13 sektor. Kegiatan ini dilaksanakan dan diberikan kepada anggota Jemaat yang diwakili oleh Sekertaris Jemaat GPM untuk diteruskan kepada setiap sektor pelayanan.

\section{Metode Pelaksanaan}

Metode pelaksanaan adalah pemberian sosialisasi edukasi terkait COVID-19 dan upaya meningkatkan spiritualitas umat. Kegiatan ini berupaya untuk mengedukasi umat dan masyarakat tentang kesadaran menerapkan 5M dan upaya meningkatkan spiritualitas umat dalam beribadah, baik secara offline dan online melalui webinar dengan menggunakan aplikasi zoom.

Dalam memberikan pemahaman yang baik terkait masalah COVID-19 dan juga proses kebaktian di rumah, maka langkah-langkah kegiatan yang dilaksanakan dalam proses ini sesuai dengan kondisi dan situasi yang dibatasi oleh PPKM (Pemberlakuan Pembatasan Kegiatan Masyarakat) di Kota Ambon. Hal ini yang mempermudah kelompok untuk menjangkau mitra yakni Jemaat GPM Ebenhaezer.

Adapun tahapan dari setiap langkah kegiatan yang dilaksanakan oleh kelompok 1 adalah sebagai berikut:

a. Tahap Persiapan:

1) Kegiatan dilakukan pada saat KKN yang dimulai dari tanggal 5 Juli 2021 sampai 16 Agustus 2021. Awal kegiatan kelompok membuat proposal untuk dilaksanakan di mitra. Selanjutnya kelompok 1 mengadakan pertemuan dengan jemaat Mitra dalam hal ini Ketua Majelis Jemaat GPM Ebenhaezer. 
2) Langkah berikutnya beberapa kegiatan yang disampaikan dalam proposal dapat dilaksanakan secara luring (offline) dengan memperhatikan protokol kesehatan yang ada, dan juga dilakukan secara daring (online). Kelompok kemudian melakukan persiapan terkait dengan kegiatan daring (online) berupa webinar, Kelompok 1 kemudian menghubungi narasumber atau Pemateri yakni: pemateri 1. dr. Lita Tarumaselej, M.KM dan pemateri 2. Pdt. Dr. Nancy N. Souisa, M.Si untuk menjadi narasumber dalam kegiatan Webinar yang dilaksanakan pada 1 Agustus 2021. Kelompok juga mempersiapkan alat dan bahan yang diperlukan dalam menunjang kegiatan seperti, fasilitas Zoom untuk 500 orang, pembuatan Flayer kegiatan untuk dipublikasikan melalui media sosial serta serta menyiapkan sertifikat untuk kedua pemateri.

3) Kegiatan luring seperti: pembelian makser, sabun cuci tangan, dan Tissue. Waktu yang dibutuhkan oleh kelompok dalam mempersiapkan bahan-bahan tersebut adalah 2 hari.

4) Langkah selanjutnya Kelompok 1 melakukan foto bersama untuk pembuatan Spanduk. Spanduk dibuat sebanyak 3 buah yang dipasang di 3 lokasi dalam Daerah Skip. Dan kelompok mencetaknya ditempat percetakan "Fokus". Kelompok membutuhkan waktu 1 hari dalam persiapanya.

\section{b. Tahap Pelaksanaan:}

1) Pelaksanaan Webinar dengan tema: "Fenomena COVID-19 dan Peningkatan Spiritualitas Umat", yang menjadi pertisipan yaitu anggota jemaat dari ketujuh Jemaat asal (Jemaat Kategorial Polri Bukit Kasih, Jemaat Bukit Doa, Jemaat Syaloom, Jemaat Imanuel dan Jemaat GPM Ebenhazer). Namun, kami dalam pelaksanaanya tidak sendiri, ada juga TIMPELDAH (Tim Pelayanan Ibadah Ebenhaezer) dibagian Multimedia untuk pemasangan zoom ke infokus untuk digunakan bagi para katekisan di gereja.

2) Pemberian masker dilaksanakan di Kantor Gereja Ebenhaezer Dan diterima baik oleh pihak Majelis jemaat.

3) Pemasangan Spanduk di 3 lokasi skip (Jembatan putih, Tempat putar mobil angkutan umum, dan Gereja Gloria baru). Pemasangan ini juga melibatkan salah satu pemuda. Karena dia mahir dalam pemasangan spanduk.

\section{c. Tahap Evaluasi}

Kegiatan-kegiatan PKM ini akan dievaluasi oleh TIM KKN-LSPB dan reviewer.

\section{Hasil dan Luaran Yang Dicapai}

Dari rencana pelaksanaan kerja yang telah dibuat dan disepakati dalam rapat kelompok bersama mitra, maka kegiatan yang ditetapkan adalah 3 kegiatan, yakni:

\section{a. Pelaksanaan Webinar}

Pelaksanaan kegiatan Webinar dengan tema: "Fenomena COVID-19 dan Peningkatan Spiritualitas Umat", menghadirkan berbagai partisipan bukan saja dari jemaat mitra saja tapi juga dari beberapa jemaat yang berada di Klasis Kota Ambon yang merupakan tempat tinggal para mahasiswa KKN-LSPB. Adapun partisipannya terdiri dari Mahasiswa KKN-LSPB, Universitas Kristen Indonesia Maluku (UKIM) kelompok 1, warga jemaat dari Jemaat Kategorial Polri Bukit Kasih, Jemaat Bukit Doa, Jemaat Syaloom, Jemaat Imanuel dan Jemaat GPM Ebenhazer. Jumlah partisipan yang hadir di media zoom berjumlah 59 orang, sedangkan di gedung gereja berjumlah $>60$ orang (katekisasi + pengajar).

Proses pelaksanaan webinar, diawali dengan arahan dari Ketua Majelis Jemaat Ebenhaezer, yang berharap bahwa melalui kegiatan ini dapat menumbuhkan kesadaran umat tentang bahaya COVID-19 dan pentingnya kesadaran untuk selalu berharap pada Tuhan lewat ungkapan syukur dan doa melalui ibadah yang baik dan benar. Selain itu juga melalui materi webinar ini kiranya menjadi masukan yang bermakna bagi para katekisan dalam memperdalam materi ajar yang dipelajari oleh anak-anak katekisasi pada semester yang sedang berlangsung. Pelaksanaan webinar ini kelompok juga didampingi oleh TIMPELDAH (Tim Pelayanan Ibadah Ebenhaezer). Tim ini bukan sekedar mendampingi tapi juga membantu dalam bagian Multimedia, terutama pada pemasangan zoom ke infokus sehingga dapat dilihat oleh para peserta webinar. 
Proses pelaksanaan webinar ini dibawakan oleh 2 narasumber. Pertama, Ibu dr Lita Tarumaseli, M.KM. yang dalam materinya banyak memaparkan tentang awal COVID samapai dengan proses penyebarannya, dampak bagi manusia yang tidak mentaati protokol kesehatan dan manfaat 5M bagi kehidupan manusia di masa COVID-19. Intinya bagi dokter Lita, mulai dini kita harus belajar hidup sehat, turuti kebijakan pemerintah agar dapat memutuskan mata rantai penyebaran COVID-19, dokter Lita juga menyinggung pentingnya spiritualitas umat dalam upaya menghadirkan Tuhan sebagai pencipta dan yang Maha kuasa dalam menguatkan iman umatnya dalam menghadapi penyebaran COVID-19. Selanjutnya Pdt. Dr. N.N Souisa, M.Si, kemudian menyabarkan pentingnya spiritualitas umat dalam menghadapi kondisi yang terjadi saat ini. Upaya untuk bukan saja menuruti kebijakan pemerintah tapi juga landasan iman untuk saling menguatkan baik dalam hidup berkeluarga, bertetangga dan berjemaat/ bermasyarakat, haruslah mengandalkan Tuhan.

Berbagai tips maupun cara-cara dalam meningkatkan spiritualitas umat melalui ibadah-ibadah pun diulas dengan mendalam bagi jemaat sebagai partisipan bahkan pengalaman-pengalaman iman yang dihadapi oleh teman ataupun keluarga yang merupakan penyintas COVID-19 sebenarnya membantu umat untuk saling menguatkan, saling mendoakan dan saling memberikan support yang mampu memberikan sukacita untuk tetap berjuang mengatasi kondisi COVID-19 ini. Kesempatan tersebut digunakan oleh salah satu mahasiswa KKN-LSPB dalam menyampaikan pengalamannya selama berada di tempat isolasi terpusat di asrama haji. Webinar yang dilaksanakan dalam 2 sesi, yakni sesi pemaparan materi dan sesi tanya jawab berjalan dengan baik. Banyak partisipan yang sangat antusias memberikan pertanyaan. Hal ini menunjukkan bahwa kesadaran umat sudah mulai muncul. Keingintahuan umat mengenai bahaya COVID dan peningkatan spiritualitas umat semakin digali secara mendalam berdasarkan berbagai pertanyaan yang disampaikan kepada para pemateri.

Akhirnya dapat terlihat kepuasaan umat melalui hasil pre test dan post test yang diambil diawal materi disampiakan dan diakhir materi disampaikan. Untuk presentasi pre test, di dapati hanya 50\% patisipan yang memahami COVID-19 dan spiritualitas umat dalam beribadah, namun pada akhir materi disampaikan hasil post test menunjukkan $80 \%$. Hal ini menunjukkan bahwa bukan keingitahuan umat saja mengenai COVID-19 tapi juga sudah mulai timbul kesadaran umat pentingnya protokol kesehatan terhadap diri pribadi tetapi juga upaya untuk selalu mendekatkan diri kepada Tuhan. Kegiatan webinar ini memakan waktu 3 jam dari waktu yang ditetapkan 2 jam dikarenakan animo penanya yang semakin banyak. Dan waktu tambahan yang diberikan tersebut telah memberikan kepuasan bagi umat dalam memahami secara mendalam pentingnya kesadaran umat dalam memberlakukan protokol kesehatan dan meningkatkan spritualitas umat dalam pelaksanaan ibadah dari dan di rumah di masa pandemic COVID-19 sebagai wujud mempertahankan kehidupan di tengah pandemic COVID-19.
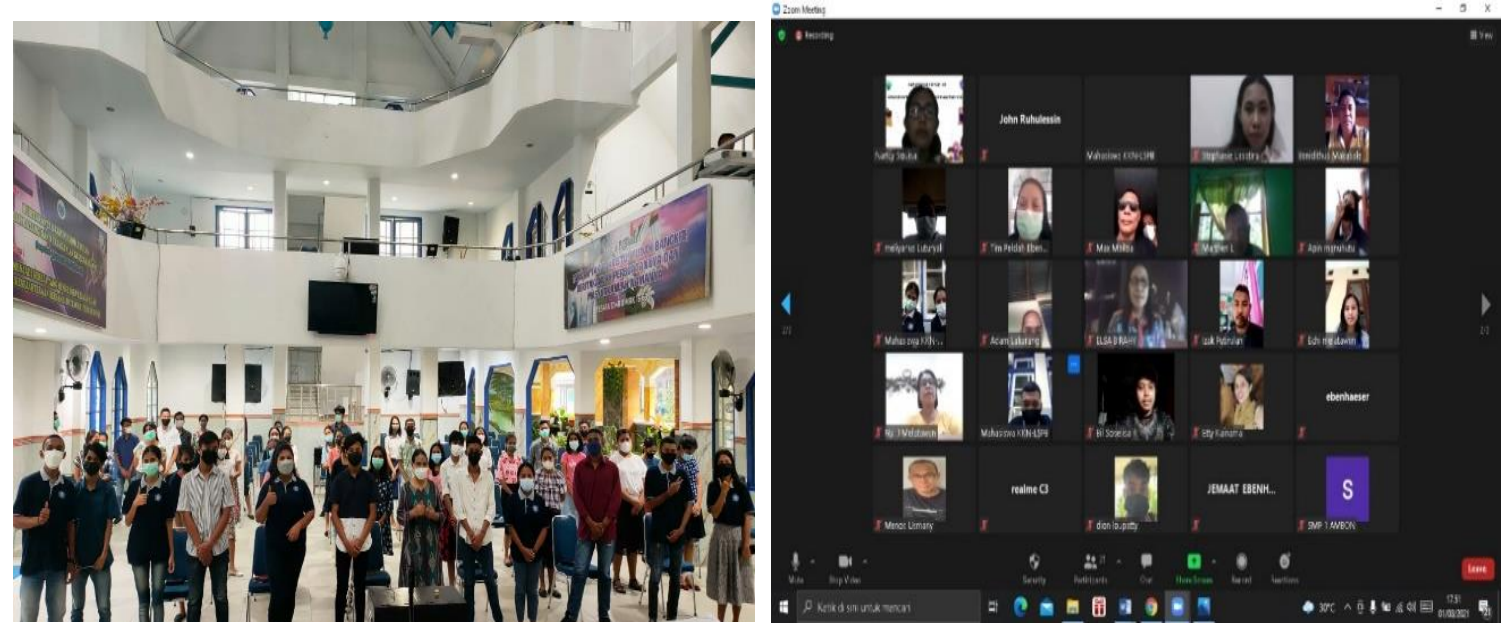

Gambar 1. Pelaksanaan Kegiatan Webinar Sumber: Dokumen Kelompok 1 KKN-LSPB

\section{b. Pemberian masker, sabun cuci tangan dan tissue}


Mahasiswa KKN-LSPB Kelompok 1 memberikan donasi berupa masker, sabun cuci tangan dan tissue kepada warga Jemaat GPM Ebenhaezer sebagai mitra. Kegiatan ini dilakukan dengan tujuan untuk menjalankan salah satu program, yaitu menaati protokol kesehatan 5M. Sebelum memberikan, kelompok terlebih dahulu mempersiapkan barangbarang dimaksud, kemudian disalurkan melalui gereja yang diwakilkan oleh sekretaris jemaat yaitu Bapak Pnt Benny Makasale dengan tetap mematuhi protokol kesehatan. Kemudian akan dibagikan kepada warga jemaat dari sektor 1 sampai sektor 13. Kegiatan ini dilaksanakan pada hari Sabtu, 07 Agustus 2021 yang bertempat di kantor jemaat GPM Ebenhaezer Skip, Ambon. Pemberian donasi ini, diterima baik oleh Majelis Jemaat dalam hal ini pegawai kantor jemaat dan sekertaris jemaat yang ditandai dengan ucapan terima kasih.
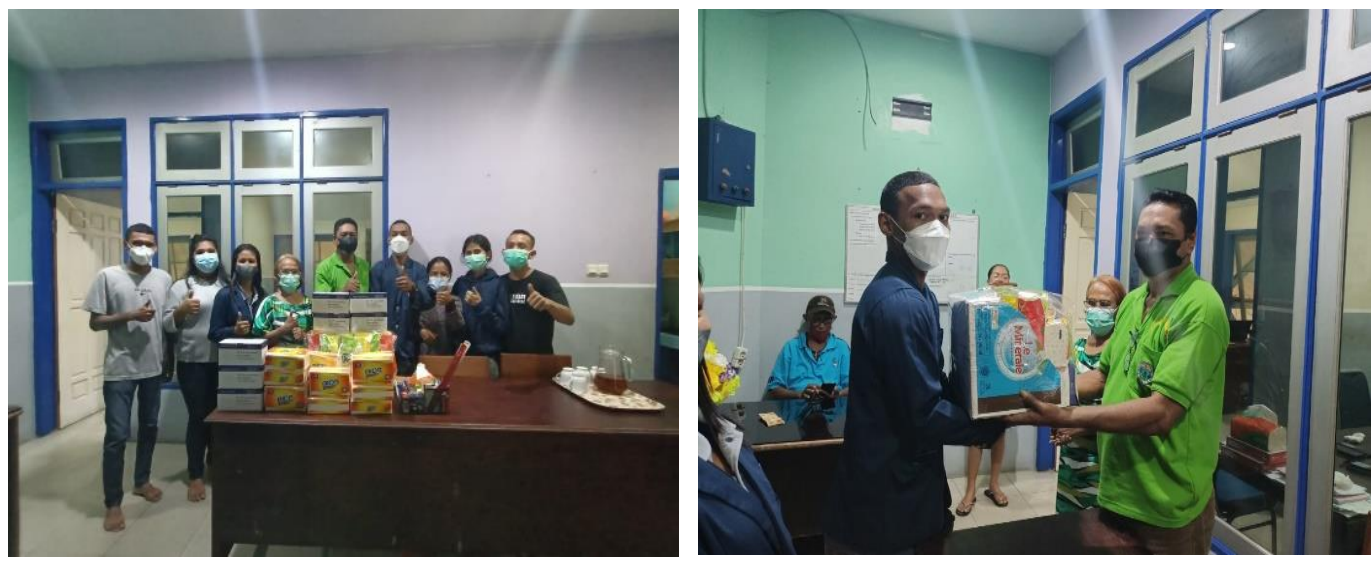

Gambar 2. Pemberian Masker, Sabun Cuci Tangan dan Tissue kepada Warga Jemaat Ebenhaezer melalui Majelis Jemaat.

Sumber: Dokumen Kelompok 1 KKN-LSPB

\section{c. Pemasangan Spanduk Protokol 5M}

Pemasangan Spanduk di lakukan pada tanggal 06 Agustus 2021 yang bertempat di 3 lokasi Skip (jembatan putih, tampa putar oto, dan Gereja Gloria baru), sebelum pemasangan spanduk dilakukan sudah ada kesepakatan bersama antara mahasiswa KKN-LSPB kelompok 1 dengan Majelis Jemaat GPM Ebenhaezer dan juga Keluarga terkait guna meminta ijin dari keluarga yang memiliki lokasi rumah dipandang baik untuk dipasangkan spanduk. Tujuannya untuk mengingatkan warga jemaat GPM Ebenhaezer untuk terus mematuhi protokol kesehatan 5M. Pemasangan spanduk dilakukan oleh mahasiswa KKN-LSPB dan juga dibantu oleh salah seorang pemuda yang bersedia membantu kelompok dalam pemasangan spanduk di 3 lokasi. Dalam prosesnya kelompok menghadapi kendala, seperti hujan, namun kelompok tetap melaksanakan pemasangan spanduk di 3 lokasi yang telah dipilih.

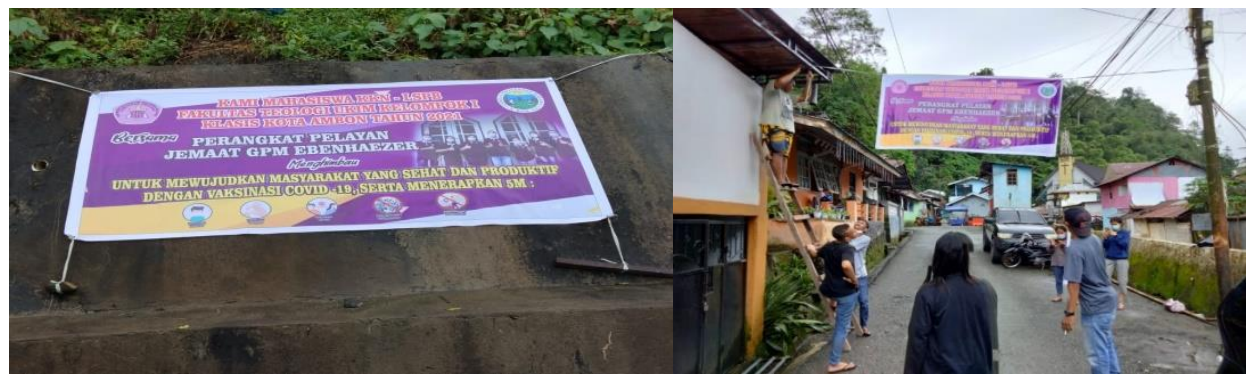

Gambar 3. Pemasangan spanduk protocol kesehatan $5 \mathrm{M}$ Sumber: Dokumentasi Kelompok 1 KKN-LSPB 


\section{Kesimpulan}

Peningkatan Spritualitas dari anggota Jemaat GPM Ebenhaezer sangatlah kurang akan kesadaran pentingnya peribadahan. Berangkat dari konteks tersebut kelompok merasa bahwa kesadaran warga jemaat untuk beribadah dari dan di rumah perlu ditingkatkan. Dan kurangnya penerapan protokol kesehatan 5M dalam memakai masker, mencuci tangan, menjaga jarak, mengurangi mobilitas dan menghindari dan kurang sadar dengan pentingnya vaksinasi. Vaksinasi diperlukan supaya dapat meningkatkan herd imunity atau kekebalan kelompok sehingga angka penyebaran virus secara luas dapat ditekan. Guna menjawab problematic konteks ini, maka kelompok melaksanakan kegiatan edukasi berupa pemberian masker, sabun cuci tangan, tissue dan webinar dengan tema "Fenomena COVID-19 dan peningkatan spiritualitas umat" di Jemaat GPM Ebenhaezer. Kedua masalah ini juga merupakan gumulan bersama dalam Jemaat GPM Ebenhaezer, karena warga anggota jemaat juga belum semua yang mematuhi aturan yang ada tentang Protokol kesehatan 5M dan begitu juga dengan proses peribadahan sehingga, peribadahan yang dilakukan juga tidak ada keseriusan dalam beribadah karena warga jemaat semuanya berfokus pada aktivitas masing-masing. Melalui kegiatan ini, kami berharap anggota jemaat GPM Ebenhaezer teredukasi tentang COVID-19 dan dampaknya bagi masyarakat termasuk kegiatan bergereja, sehingga mereka dapat secara sadar melakukan ibadah dari dan di rumah masing-masing dengan benar sebagai wujud bersama dalam mempertahankan kehidupan di tengah pandemic COVID-19.

\section{References}

Ade Miranti Karunia. (n.d.). Imbas Corona, Lebih dari 3,5 Juta Pekerja kena PHK dan Dirumahkan.

Baloch, S., Baloch, M. A., Zheng, T., \& Pei, X. (2020). The coronavirus disease 2019 (COVID-19) pandemic. In Tohoku Journal of Experimental Medicine (Vol. 250, Issue 4). https://doi.org/10.1620/tjem.250.271

Ebenhaezer, M. G. (n.d.). Rencana strategis Jemaat GPM Ebenhaezer 2021-2025,.

Instruksi Walikota Ambon. (2021). Instruksi Walikota Ambon tentang PPKM No 3 Tahun 2021.

Koritelu. (n.d.). Hasil Wawancara Dengan Ketua Majelis Jemaat GPM Ebenhaezer-Skip.

Satgas Covid-19. (2021). Peta Sebaran Covid-19. Peta Sebaran Covid-19.

Touwely, G. H., Freedom Nanuru, R., Laisila, M., \& Dandirwalu, R. (2019). Assistance on Writing Scientific Papers for Students of Nusaniwe Village. Indonesian Journal of Cultural and Community Development (IJCCD), 4(1), 23-31. https://doi.org/10.21070/ijccd.v2i3.70

Wahyu S. Wibowo. (2020). Realitas dan Hiperealitas pada Ibadah Agama di Masa Pandemi Covid-19 dalam Virus, Manusia, dan Tuhan: Refleksi Lintas Iman tentang Covid-19. Kepustakaan Populer Gramedia, 2020.

Yuliana. (n.d.). Corona Virus Diseases (Covid-19): Sebuah Tinjauan Literartur, Welness and Healthy Magazine. Wellness.Journalpress, Volume 2 N, Halaman 187-192. 